\title{
O RIACHO PAJEÚ E A CIDADE: ANÁLISE DA INFLUÊNCIA ANTRÓPICA NO CURSO DE UM RIO URBANO EM FORTALEZA, CEARÁ
}

\author{
Fábio de Oliveira Matos \\ Professor do Programa de Pós-graduação em Geografia (UFC) \\ Universidade Federal do Ceará \\ fabiomatos@ufc.br \\ Marcelo Gonçalves Dutra
Bacharel em Ciências Ambientais, pelo Instituto de Ciências do Mar, da Universidade Federal do Ceará \\ (Labomar/UFC). \\ marcelodutralabomar@gmail.com
}

\begin{abstract}
RESUMO
Este estudo tem por objetivo analisar a relação do Riacho Pajeú no contexto da paisagem urbana da cidade de Fortaleza, Estado do Ceará, procurando compreender as complexas interações antrópicas com o curso do referido riacho em seus 4.714,50 metros oficialmente reconhecidos, desde a sua nascente no bairro da Aldeota até sua foz no litoral da região central da cidade, assim como a forma de convivência de seus habitantes com esse relevante recurso hídrico. Para tanto, foram analisados registros cartográficos e de sensoriamento remoto, procurando identificar o grau de degradação de seu curso original durante o processo de urbanização da Cidade, através da sistematização da análise das imagens obtidas. Ao final é apresentado uma imagem síntese do percurso do Riacho Pajeú na atualidade, expondo a condição de "invisibilidade" do referido curso hídrico no contexto do processo de urbanização da área central de Fortaleza, apesar de sua importância ambiental e histórica.
\end{abstract}

Palavras-chave: Riacho Pajeú. Rio urbano. Paisagem.

\section{RIACHO PAJEÚ AND THE CITY: ANALYSIS OF THE ANTHROPIC INFLUENCE ON THE COURSE OF AN URBAN RIVER IN FORTALEZA, CEARÁ}

\begin{abstract}
This study aims to analyze the relationship of Riacho Pajeú in the context of the urban landscape of the city of Fortaleza, State of Ceará, seeking to understand the complex anthropic interactions with the creek course in its $4,714.50$ meters officially recognized, since the its source in the neighborhood of Aldeota until its mouth on the coast of the central region of the city, as well as the way of living of its inhabitants with this relevant water resource. For that, cartographic and remote sensing records were analyzed, trying to identify the degree of degradation of its original course during the process of urbanization of the City, through the systematization of the analysis of the images obtained. At the end, a summary image of the route of the Pajeú Stream is presented today, exposing the condition of "invisibility" of the referred water course in the context of the urbanization process of the central area of Fortaleza, despite its environmental and historical importance.
\end{abstract}

Keywords: Pajeú stream. Urban river. Landscape.

\section{INTRODUÇÃO}

Ao longo da história urbana brasileira, nota-se o estabelecimento de uma estreita conexão entre rios e cidades, sendo palco comum a formação de urbis às margens de cursos hídricos de diferentes dimensões, em função dos seus benefícios oferecidos, ambientais ou não, como: fornecimento de água, recursos pesqueiros, mobilidade (navegação), circulação de bens e serviços, controle territorial e outros mais. Assim, com o aumento populacional e a crescente urbanização das cidades, os rios foram sendo gradativamente incorporados à paisagem urbana, sendo em sua maioria tragados pelas vias e construções, buscando sobreviver ao caótico e desenfreado modelo de expansionismo adotado no país, à sobrevalorização e a especulação imobiliária. 
Não são somente as ocupações irregulares e ilegais às suas margens que causam prejuízos, muitas vezes irreversíveis, a esses corpos hídricos. Grandes e custosos empreendimentos imobiliários e complexos projetos (públicos e privados) parecem desconhecer a importância desses ambientes para a qualidade de vida de seus habitantes, sua importância ecológica para fauna e flora, seus serviços ambientais, bem como a degradação causada ao que chamamos de paisagem urbana (BOBADILHO, 2014). O Quadro 1 apresenta uma síntese das atividades humanas sobre os rios urbanos e suas consequências.

Quadro 1 - Impactos das atividades antrópicas sobre os rios urbanos e suas consequências.

ALTERAÇÕES SOBRE RIOS URBANOS
RESULTANTES DA AÇÃO ANTRÓPICA

POLUIÇÃO POR MEIO DE FONTES INDUSTRIAIS (FONTES PONTUAIS E DIFUSAS).

\section{POLUIÇÃO POR MEIO DE FONTES RESIDENCIAIS} (ELIMINAÇÃO DE ESGOTOS NÃO TRATADOS).

INTRODUÇÃO DE ESPÉCIES EXÓTICAS.

REMOÇÃO DA VEGETAÇÃO RIPÁRIA (MATA CILIAR OU DE GALERIA).

\author{
CONSTRUÇÃO DE CANAIS, PONTES E \\ PASSAGENS.
}

\section{DRENAGEM URBANA.}

\section{PRINCIPAIS CONSEQUÊNCIAS}

Eliminação, extinção, desequilíbrios nas comunidades de fauna e flora em função do aporte de metais pesados e esgotos não tratados.

Perda da biodiversidade em função do aporte de efluente sanitário bruto - níveis elevados de nitrogênio $(\mathrm{N})$ e fósforo $(\mathrm{P})$.

Alteração da rede alimentar e do processo natural de interação das comunidades.

Diminuição da matéria orgânica à disposição de peixes e invertebrados. Ausência de proteção às margens e aos taludes, com alteração da morfometria.

Interferência no fluxo de energia dos rios; Alteração do substrato (composições química e física).

Contaminação da água por resíduos domésticos e industriais.

Fonte - Adaptado de Tundisi; Tundisi (2008).

Define-se rios urbanos como elementos de curto e médio curso, inseridos totalmente nos limites municipais e, portanto, sofrem praticamente as mais diversas pressões na totalidade de seus cursos, da nascente à foz. Tratam-se, portanto, de ambientes de resiliência comprometida porque possuem baixa possibilidade de se auto depurar tanto pela quantidade e concentração de poluentes quanto pelas suas pequenas extensões (ALMEIDA, 2010; ANDRADE e MATOS, 2016).

Para o presente estudo, voltado para o papel dos rios urbanos, foi selecionado o Riacho Pajeú, situado na cidade de Fortaleza e localizado entre os bairros Centro e Aldeota, zona eminentemente comercial e residencial, a qual teve grande parte de seu curso reconfigurado, canalizado ou soterrado durante a expansão urbana da capital cearense. Considerado um dos principais elementos ambientais a contribuir para a fixação humana na gênese da ocupação do espaço que viria a se tornar Fortaleza, o Riacho Pajeú foi escolhido como objeto de estudo com o objetivo de analisar a transformação da paisagem ao longo do referido curso hídrico, desde a nascente até sua foz, identificando seu traçado original e atual, bem como as interferências antrópicas ocorridas em seu curso e suas implicações para a paisagem urbana de Fortaleza.

Para alcançar o objetivo traçado, foram elencados como objetivos específicos: Identificar o traçado original e atual do curso do Riacho Pajeú; Identificar e mapear as interferências antrópicas; Analisar como se processaram essas interferências em toda a extensão do mesmo. 


\section{MATERIAIS E MÉTODOS}

A obtenção de dados que subsidiou este estudo deu-se através dos seguintes pontos:

- Levantamento de material iconográfico em bibliotecas, bases de dados e internet;

- Consulta aos projetos urbanísticos no Arquivo Público / Prefeitura de Fortaleza;

- Uso de imagens georreferenciadas disponibilizadas através do aplicativo Google Earth Pro ${ }^{\circledR}$ de 2017;

- Pesquisa bibliográfica em bibliotecas de instituições de ensino superior e de órgãos ambientais situados na cidade de Fortaleza;

- Investigação de bases cartográficas no acervo da biblioteca do curso de Arquitetura e Urbanismo da Universidade Federal do Ceará (UFC), no Arquivo Público, Instituto do Patrimônio Histórico e Artístico Nacional (IPHAN) e na biblioteca da Superintendência Estadual do Meio Ambiente (SEMACE);

- Coleta de dados de campo, através de incursões a pé, para aquisição de dados referentes às interferências urbanísticas e outras no período de setembro a outubro de 2017;

- Análise e sistematização das informações / dados obtidos através de softwares de tratamento de imagens fotográficas e de sensoriamento remoto;

- Entrevistas informais com a população do entorno do curso do Riacho Pajeú.

Com relação ao norteamento teórico, adotou-se o conceito de paisagem como sendo a resultante de um processo contínuo de acumulação de processos espaciais sob um complexo mosaico de percepções e estruturas moldadas ao longo do tempo. Compõe-se de um conjunto de formas e funções com atributos em constante transformação, no qual a sociedade se subordina às diretrizes do espaço preexistente, o que o torna uma totalidade tanto verdadeira quanto dinâmica. Ela imprime indeléveis sensações que se materializam no modo de perceber o meio circundante ao mesmo tempo que, consciente ou inconscientemente, imprime marcas da própria sociedade nessa mesma paisagem. Desse modo, não se pode limitar aos sentidos para "perceber" a paisagem em sua totalidade e complexidade. Assim como não se pode reduzi-la a uma microescala de análise tal a sua complexidade intrínseca, limitando-a espacial e temporalmente (SERPA, 2010).

Paisagem, invariavelmente, pressupõe refletir fatores sociais, culturais, econômicos, que replicam os valores estabelecidos por grupos dominantes de nossa sociedade, codificadas em elementos visíveis e invisíveis, concretos e abstratos, que alimentam esse processo de retroalimentação de nossas percepções e pré-disposições (COSGROVE, 1998).

Assim, diante do desafio em analisar a transformação da paisagem ao longo do curso do Riacho Pajeú, foram realizadas pesquisas em órgãos públicos para obtenção de dados, imagens e relatos sobre a nascente, curso e foz do referido riacho. Com a finalidade de padronizar a metodologia de estudo, considerou-se o levantamento realizado pelo Serviço Geográfico do Exército Brasileiro, de 1945, que resultou na "Carta da Cidade de Fortaleza e Arredores" (Figura 1A), consultada nos arquivos da biblioteca do curso de Arquitetura e Urbanismo da Universidade Federal do Ceará (UFC). Optou-se pela referida Carta em virtude da reconhecida expertise do Exército Brasileiro em elaborar estudos cartográficos precisos e apurados à época, com alto nível de detalhamento.

Tal Carta foi digitalizada e sua folha 3 (na qual está inserida a área de estudo), sobreposta à imagem atual de satélite (Figuras 1B), obtidas através do aplicativo Google Earth Pro ${ }^{\circledR}$. Nessa sobreposição, realizada com o software Adobe Photoshop ${ }^{\circledR}$ versão 6.0, uso educacional, foi possível comprovar o elevado grau de precisão da imagem elaborada pelo Exército, com alta correspondência de elementos às referidas imagens atuais. Considerou-se, portanto, a nascente e o curso do riacho constantes nesta Carta.

Em seguida, isolou-se o traçado do curso do Riacho Pajeú constante na mencionada Carta e aplicouse tal traçado, sobreposto e de forma realçada, à imagem atual de satélite obtida através do aplicativo Google Earth Pro $^{\circledR}$, utilizando-se a mesma versão do software Adobe Photoshop ${ }^{\circledR}$.

Uma vez sobrepostas as imagens, o curso foi subdividido em cinco quadrantes (ver Figura 2 e Quadro 2), desde sua nascente até sua foz, visando possibilitar uma melhor disposição do curso do rio para a presente análise. Em seguida, em visitas de campo empreendidas entre os anos de 2017 a 2019, a pé, acompanhou-se o curso do rio em toda a sua extensão, realizando registro fotográfico, sempre quando possível, para documentação das condições atuais em que se encontram os referidos trechos. Desse modo, procurou-se traçar um histórico de ocupação e uso do entorno do Riacho Pajeú através de textos, documentos e relatos acerca do seu processo de constituição urbana. 
Figura 1 - A: Detalhe do mapa elaborado em 1945 pelo Serviço Geográfico do Exército indicando o curso (em azul) do Riacho Pajeú; B: Sobreposição com a imagem de satélite do Google Earth (2017) e indicação do curso do riacho (em azul).

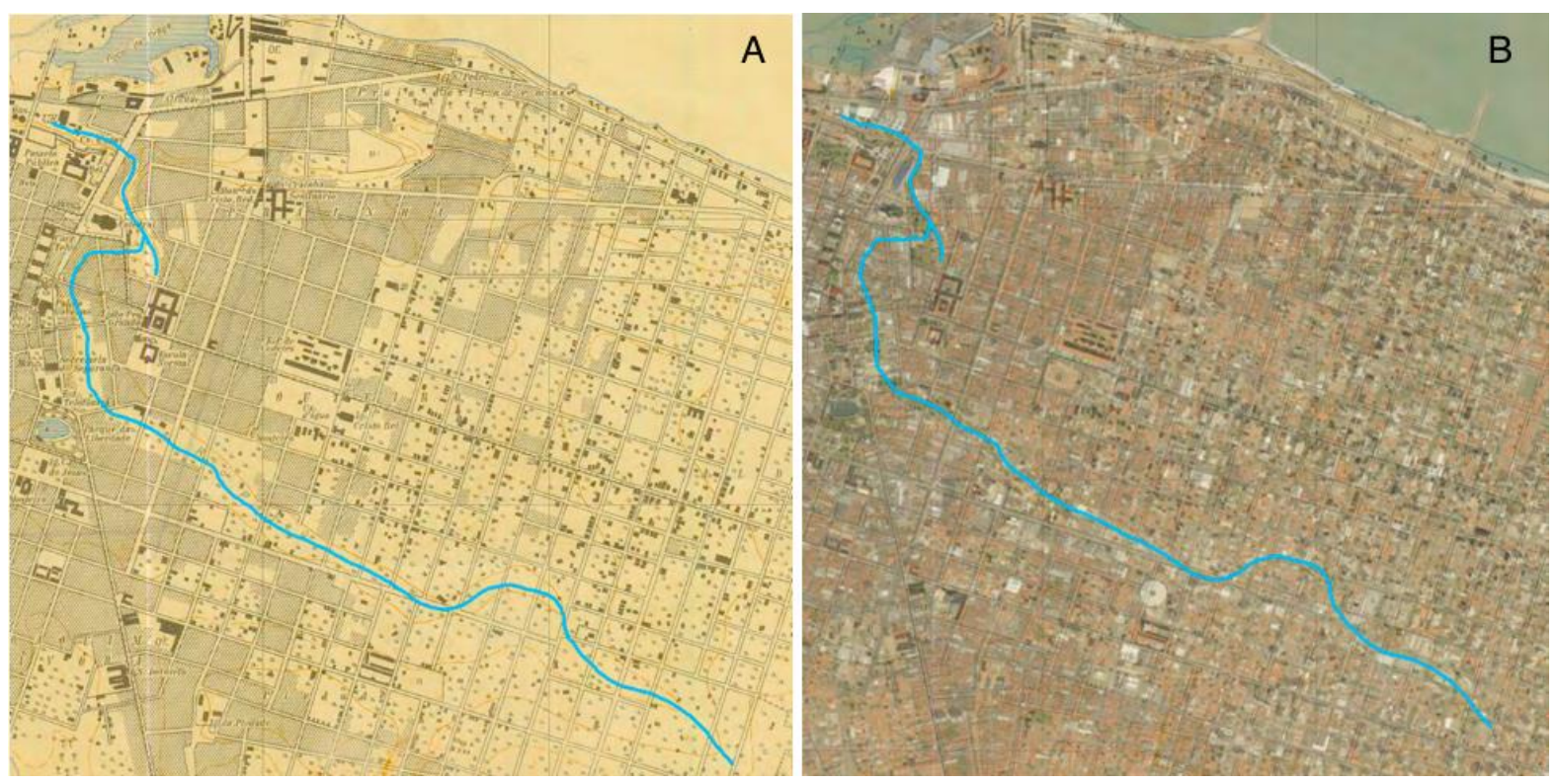

Fonte - Adaptado do serviço Geográfico do Exército e Google Earth Pro ${ }^{\circledR}$ (30/09/2017). Escala 1:10.000.

Figura 2 - Sobreposição final do traçado do curso do Riacho Pajeú (em azul) com a imagem de satélite do Google Earth (2017) e divisão do curso em quadrantes, para análise detalhada da situação atual do mesmo.

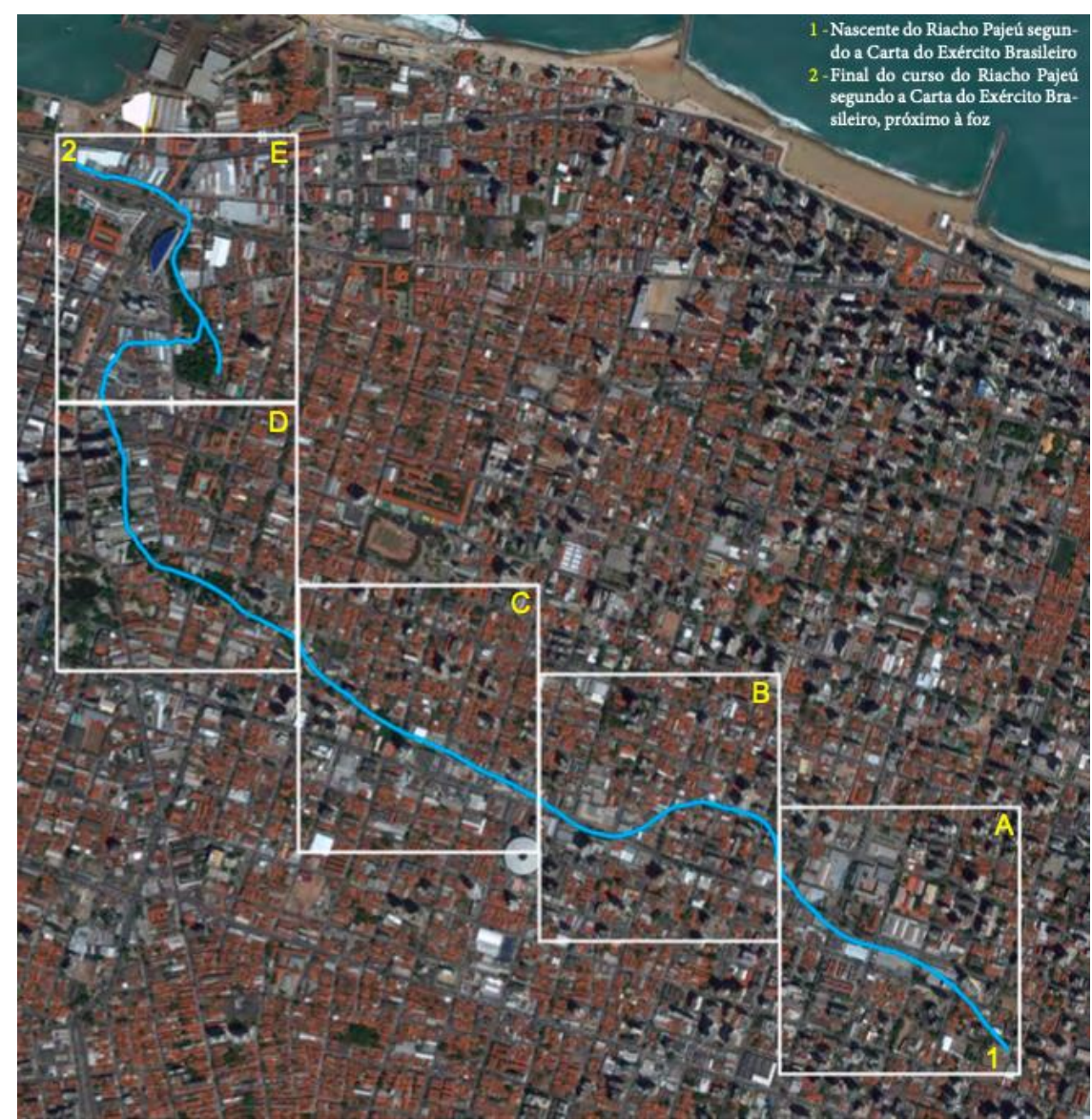

Fonte - Adaptado do Google Earth $\operatorname{Pro}^{\circledR}(30 / 09 / 2017)$. Escala 1:10.000. 
Quadro 2 - Delimitação dos Quadrantes utilizados.

QUADRANTES

A

B

C

D

E

\section{LIMITES}

Entre a Rua Joaquim Nabuco e a Rua Dr. José Lourenço.

Entre a Rua Dr. José Lourenço e a Rua Ildefonso Albano.

Entre a Rua lldefonso Albano e a Rua Rodrigues Júnior.

Entre a Rua Rodrigues Júnior e a Rua Sena Madureira.

Entre a Rua Sena Madureira e a Av. Presidente Castelo Branco.

Fonte - Elaborado pelos autores (2020).

\section{PERCORRENDO O RIACHO PAJEÚ}

O Riacho Pajeú está compreendido na Bacia da Vertente Marítima, uma faixa continental litorânea localizada entre a foz do Rio Cocó e a do Rio Ceará, com cerca de $23,6 \mathrm{~km}^{2}$, caracterizada por sua topografia favorável ao escoamento das águas de pequenas planícies aluviais recortadas da planície costeira em direção ao oceano (PREFEITURA MUNICIPAL DE FORTALEZA, 2016).

$O$ relevo local determina a calha de escoamento do referido riacho e facilita o entendimento e o estabelecimento de seu curso mesmo em regiões onde não é mais possível sua visualização. É uma área altamente antropizada em função de seu adensamento populacional e dos padrões históricos de ocupação e do processo de valorização imobiliária que tais ambientes costumam sofrer.

Outrora um dos símbolos da cidade de Fortaleza, o Riacho Pajeú é um sobrevivente do processo expansionista da cidade, estando associado ao imaginário popular e presente nas primeiras cartas, mapas e documentos referentes a esta cidade desde a sua criação (ver Figura 3). As suas margens foram edificadas as primeiras construções, antecessoras da moderna Fortaleza, além de fornecer água doce para seus primeiros habitantes e para as embarcações que aportavam em seu litoral para se reabastecer. Configura-se como um dos principais elementos macrodrenantes da região central da cidade, reforçando sua importância para o ambiente e para a manutenção da qualidade de vida da população (PREFEITURA MUNICIPAL DE FORTALEZA, 2003).

Figura 3 - Fac-símile do mapa de Matias Beck, de 1649, descrevendo o primeiro povoamento da Capitania de Siará (detalhe realçado do Riacho Pajeú, em azul).

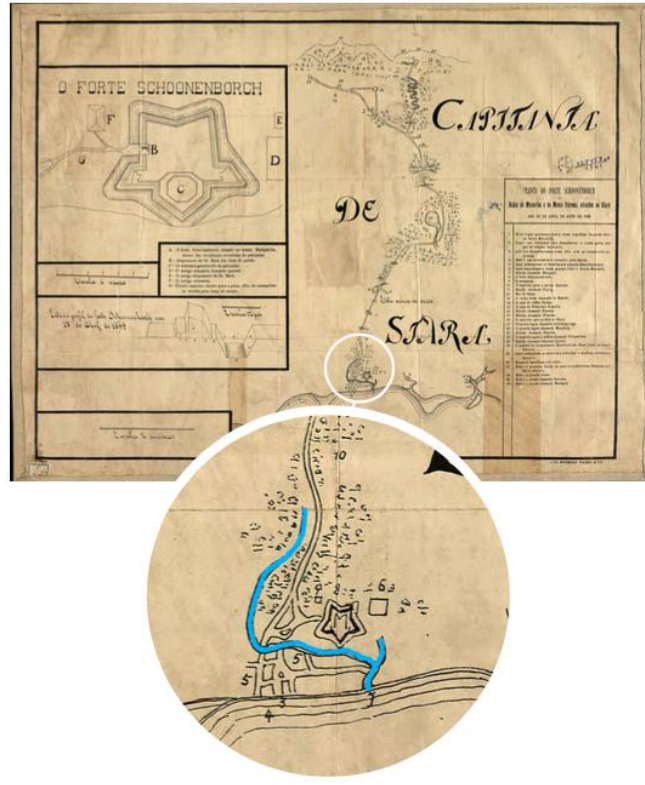

Fonte - Biblioteca Nacional (2020). 
De acordo com a metodologia adotada na Figura 1, sua nascente insere-se no quadrilátero formado pelas ruas General Tertuliano Potiguara, Joaquim Nabuco, Tibúrcio Cavalcante e Avenida Padre Valdevino, diferenciando-se do informado pela Prefeitura Municipal de Fortaleza (1981), que afirma que sua foz se encontra no quadrilátero formado pelas ruas Silva Paulet, José Vilar, Bárbara de Alencar e Dona Alexandrina. Tal imprecisão quanto à sua nascente se dá ao fato de que a referida encontra-se completamente encoberta ou canalizada, devido à expansão urbana e à especulação imobiliária no local (ver Figura 4). Seu curso possui 4.714,50 metros de extensão desde sua nascente até desembocar no mar, em trecho entre onde estão hoje edificados o Hotel Marina Park e o estaleiro da Indústria Naval Cearense, na Praia Formosa.

A seguir, apresenta-se o resultado da análise das margens do Riacho Pajeú, por meio da segmentação dos quadrantes de detalhamento.

Figura 4 - Fotografia de O. Justa, em 1919, registrando a construção do canal de escoamento do Riacho Pajeú na Rua São José, em direção aos jardins do Paço Municipal de Fortaleza.

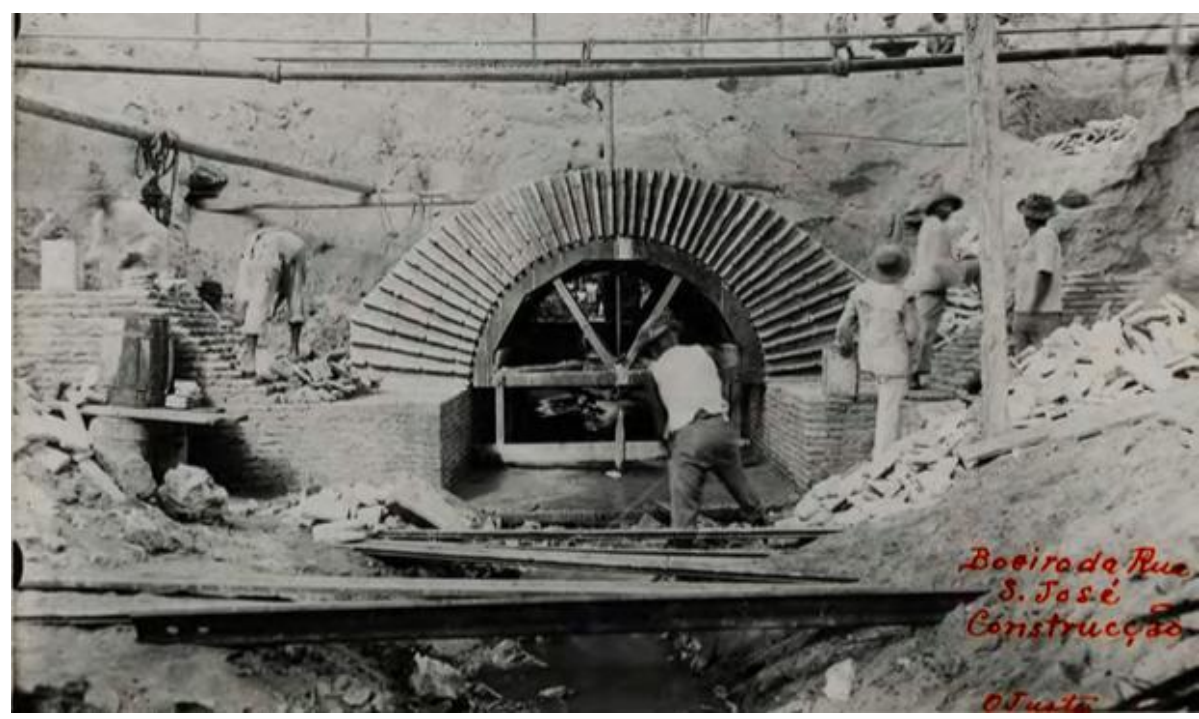

Fonte - Biblioteca Nacional (2020).

\section{Quadrante A}

Nesse segmento, observam-se as divergências quanto à sua nascente, tendo como base a Carta produzida pelo Exército e os dados fornecidos pela Prefeitura Municipal de Fortaleza. O ponto A se encontra em altitude superior do relevo em relação ao ponto B (ver Figura 5). Mesmo assim, em ambos os casos, seu curso original se encontra totalmente encoberto e invisível, não sendo possível confirmar sua nascente, em virtude de tratar-se de uma das áreas mais valorizadas da Cidade, concentrando edifícios residenciais e comerciais.

Como preconizado por Saide Kahtouni (2004), o remodelamento pelo homem dos rios através de intervenções tecnológicas objetiva ampliar a oferta de solo com o intuito de possibilitar a ocupação humana, processo que se dá concomitante- mente à perda dos antigos vínculos dessa população com seus cursos históricos. E esse processo é perfeitamente observado em toda a extensão do curso do Riacho Pajeú que atravessa o bairro Aldeota. Uma das áreas mais valorizadas da Cidade, desde sua nascente, uma parte significativa de seu curso inicial se encontra invisibilizado para a população.

A partir das visitas de campo, o local indicado pelo Serviço Geográfico do Exército como sendo o da nascente do Riacho Pajeú em nada sugere a existência da mesma. Trata-se de um terreno, no bairro da Aldeota, encravado numa das áreas de maior especulação imobiliária atualmente na cidade de Fortaleza. Segundo a Carta do Exército, porém, seria o local correto da nascente (ver Figura 6).

Como outros terrenos à espera de projetos imobiliários, e para se adequar à legislação, foi transformado em estacionamento. De chão de terra batida, ao menos contribui para a infiltração da água da chuva, em meio a uma região já quase totalmente impermeabilizada, reduzindo o escoamento superficial e minimizando episódios de alagamento. 
Figura 5 - Detalhe da localização da nascente do Riacho Pajeú, segundo informações do Serviço Geográfico do Exército $(A)$ e da Prefeitura Municipal de Fortaleza (B).

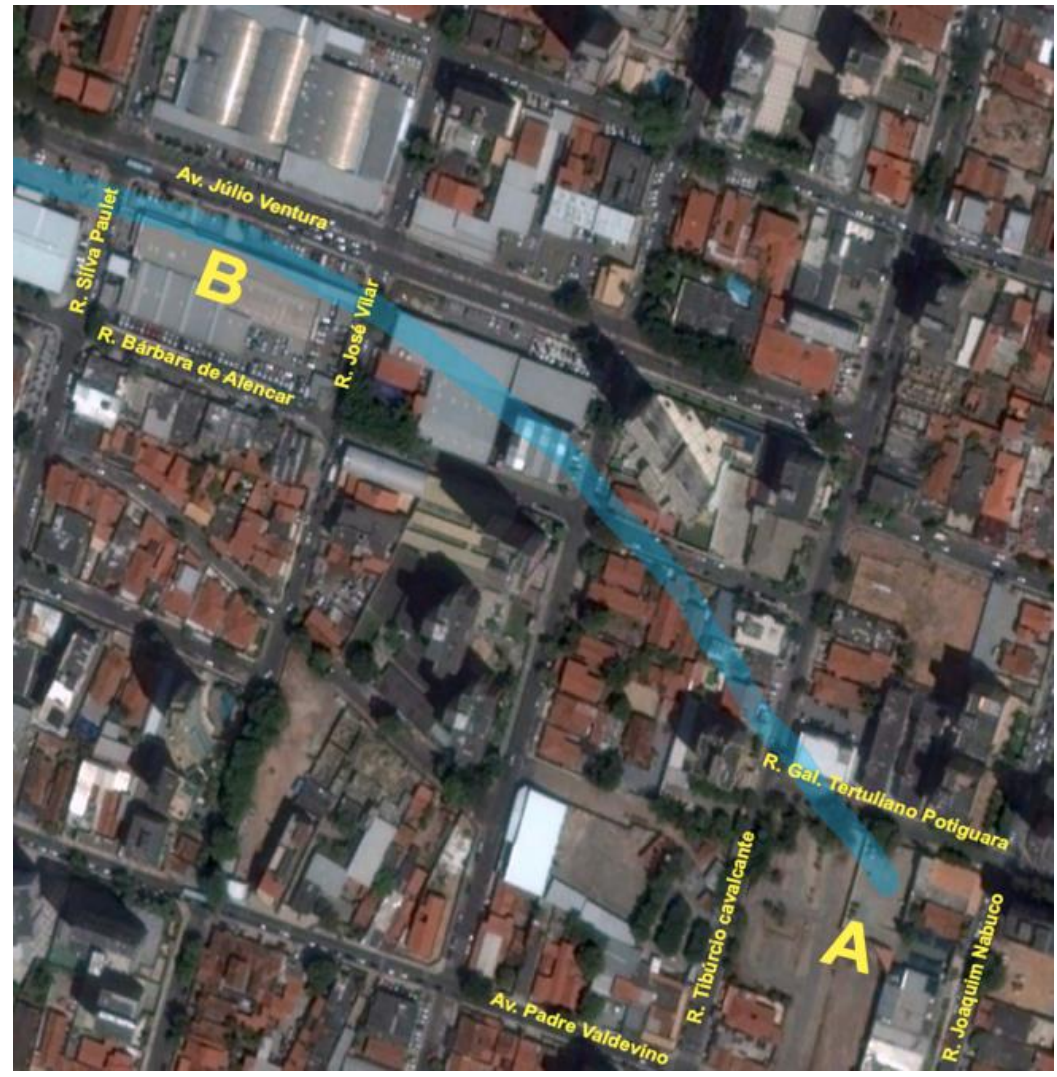

Fonte - Adaptado de Google Earth $\operatorname{Pro}^{\circledR}$ (30/09/2017). Ampliação da imagem escala 1:10.000.

Figura 6 - Imagens da localização da nascente do Riacho Pajeú segundo informações do Serviço Geográfico do Exército.

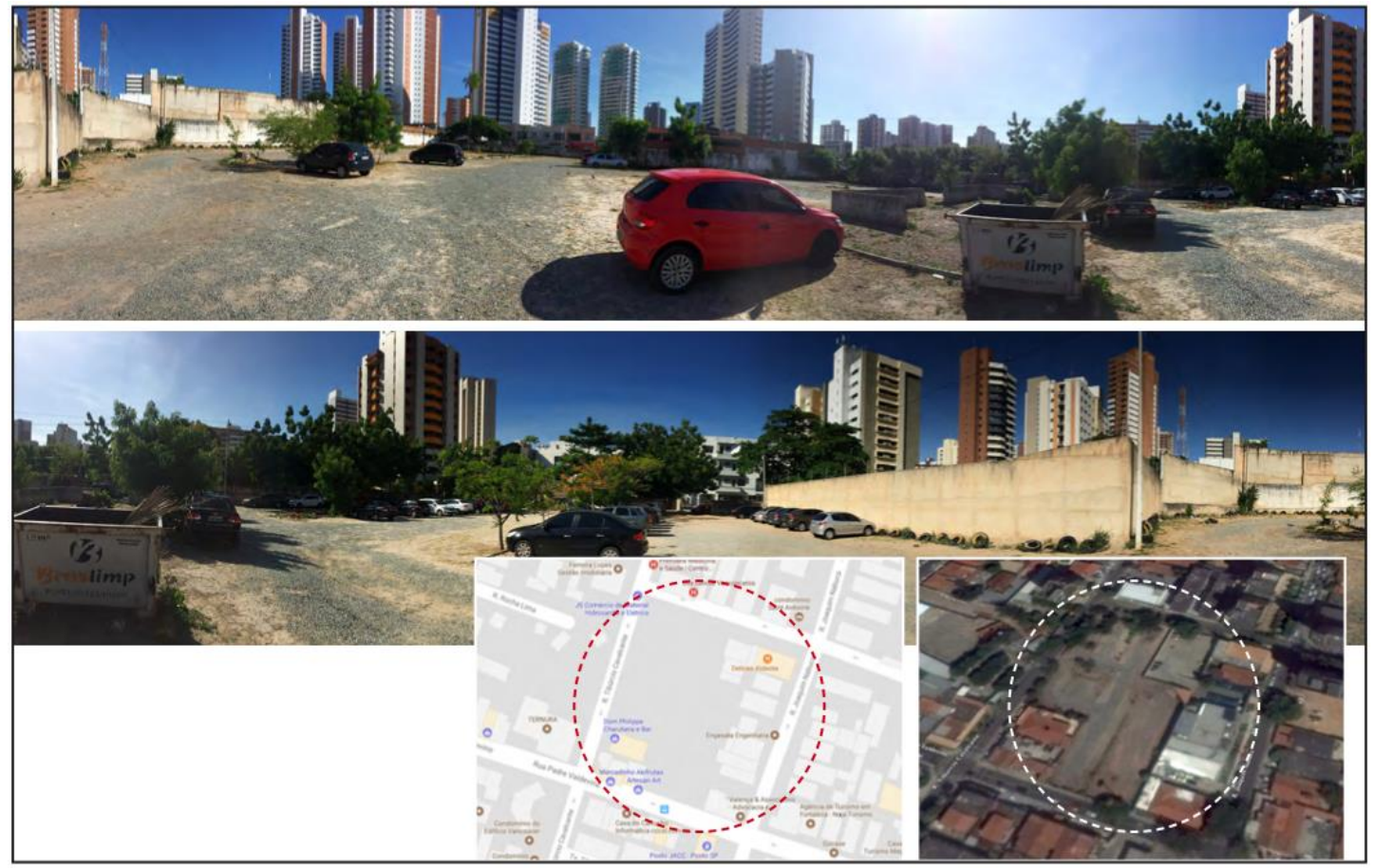

Fonte - Adaptado de Google Maps ${ }^{\circledR}$ (2017) e Google Earth Pro ${ }^{\circledR}(30 / 09 / 2017)$. 
Na parte mais elevada do relevo local, segundo observação de campo, quando da estação de chuvas uma grande quantidade de água se avoluma no terreno, correndo "tal como um rio" para a parte mais rebaixada do relevo, seguindo o que seria, naturalmente, o curso do Riacho Pajeú. A três quadras desse local, encontra-se a área apontada como origem da nascente do riacho pela Prefeitura Municipal de Fortaleza, mas, uma vez mais, nada é perceptível (ver Figura 7). No lugar avista-se uma concessionária de veículos, cercada por outros equipamentos comerciais situados às margens da Avenida Heráclito Graça. Em conversas informais com trabalhadores locais ao longo das atividades de campo empreendidas naquela área, registrou-se o desconhecimento por parte dos mesmos da presença de qualquer curso d’água ou galeria.

Isso reforça o caráter de invisibilidade do Riacho Pajeú a partir de suas supostas nascentes. O fixo mostra-se invisibilizado, enquanto que os fluxos modificam-no ano após ano, conferindo uma nova significação e alterando irreversivelmente suas características originais. Assim, numa tomada equivocada de decisão de sucessivos gestores públicos municipais, vai se perdendo o sentimento de pertencimento e identidade da população com um de seus principais símbolos históricos e ambientais, e que ao longo do tempo mostrou-se como um importante recurso hídrico para a manutenção da biodiversidade, equilíbrio ambiental e a qualidade de vida da população.

Essa região, situada no bairro Aldeota, pertence à Secretaria Executiva Regional II (SER II), e é caracterizada pelo Plano Diretor Participativo de Fortaleza (PDPFor) (2009) como uma Zona de Ocupação Consolidada (ZOC). A referida zona corresponde, literalmente, a uma descrição da mesma, pois observa-se que cada parcela daquele espaço encontra-se edificado, com a paisagem marcada por estacionamentos e empreendimentos residenciais/comerciais de alto valor agregado, que contribuem sistematicamente para a extinção da biodiversidade local e a perda da qualidade de vida da população. Nota-se que o espaço é resignificado, a paisagem é transformada e, gradativamente, os aspectos ambientais, culturais e sociais são descaracterizados, contribuindo sobremaneira para o processo de invisibilidade desse rio urbano.

Figura 7 - Imagens da localização da nascente do Riacho Pajeú segundo Prefeitura Municipal de Fortaleza (1981).

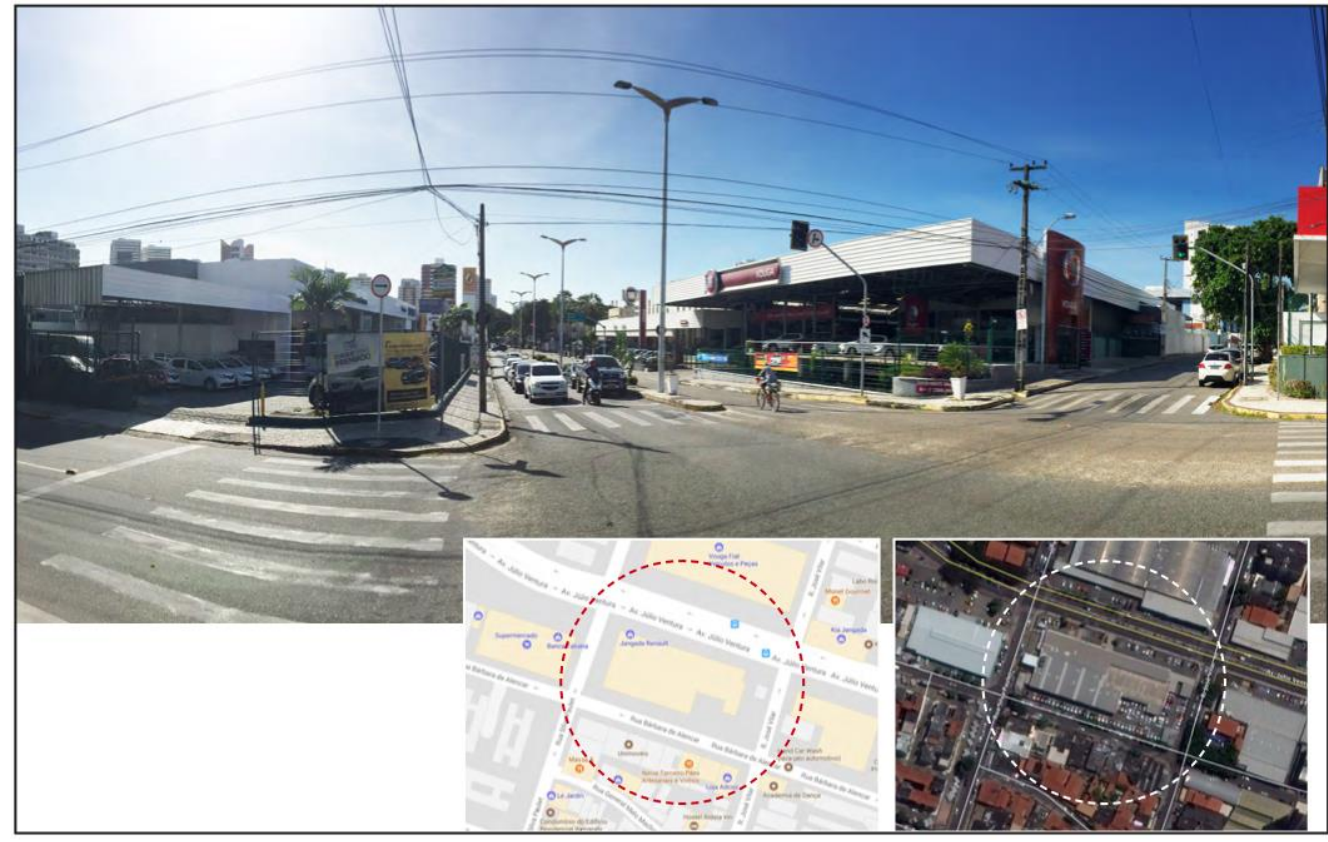

Fonte - Adaptado de Google Maps® (2017) e Google Earth Pro® (30/09/2017).

\section{Quadrante B e Quadrante C}

No segmento do Quadrante B do curso do Riacho Pajeú, repetem-se as condições encontradas no quadrante anterior, com a totalidade do curso encoberta pelo processo consolidado de urbanização da região. Seu curso continua invisível à população de seu entorno, completamente canalizado e 
correndo por sob a superfície, que se encontra altamente impermeabilizada e densamente povoada. Alternam-se empreendimentos residenciais e comerciais de múltiplos usos.

No Quadrante C, é possível identificar os primeiros afloramentos do curso hídrico em análise, sendo possível de ser observada no interior de propriedades privadas (em geral comerciais), correndo por canais de concreto ou rocha, já altamente degradados, assoreados e obstruídos por efluentes clandestinos.

$\mathrm{Na}$ análise do referido quadrante, observa-se o primeiro trecho exposto do curso do Riacho Pajeú, situado no interior de um estabelecimento comercial localizado na Avenida Heráclito Graça. Tal afloramento se constitui em um canal com aproximadamente 2 metros de largura e composta por paredes de concreto por sobre o qual, em determinado trecho, existe uma ponte de madeira para acesso ao restante do terreno, nos fundos do estabelecimento. Esse canal segue até o muro que dá para a rua lateral, onde o riacho adentra um canal fechado por sob a rua asfaltada. Em seguida, atravessa-se por uma quadra com o riacho totalmente canalizado por sob estabelecimentos comerciais diversos (escola, edifício residencial e outros).

Somente na quadra a seguir, entre as ruas Nogueira Acioli e J. da Penha, o riacho reaparece num terreno não-edificado e não-murado para, em seguida, ser novamente canalizado por sob rua, adentrando numa galeria subterrânea na quadra compreendida entre as ruas J. da Penha e D. Leopoldina. Nessa quadra, segue canalizado até sua metade, onde aflora nos fundos de um estacionamento, em terreno particular murado, onde não foi possível adentrar devido não ter sido possível localizar o proprietário. Nesse terreno, no qual existe uma moradia, ressurge entre paredes de concreto, até o limite com o muro da propriedade, onde novamente submerge por sob a rua.

Do outro lado da via, o curso hídrico adentra numa outra propriedade particular (Figura 8), onde pode ser constatado, em análise comparativa entre o observado e a descrição do Serviço de Geografia do Exército, que houve alteração do curso original do riacho com o intuito de possibilitar a edificação da propriedade ali instalada. Na segunda metade da referida quadra, segue novamente por um estreito canal de concreto de aproximadamente 1,5 metros de largura (Figura 9), em um terreno em processo de construção, até a rua Rodrigues Júnior, onde é novamente canalizado sob a referida via. Em seguida, atravessa a quadra compreendida pela rua Rodrigues Júnior e a avenida Dom Manuel (Figura 10) onde, na primeira metade, corre subterraneamente sob as construções existentes e, na segunda metade, prossegue por canal de concreto recoberto por uma laje de concreto, atravessando os jardins de uma imponente propriedade particular.

Figura 8 - Imagens de trecho exposto do curso do Riacho Pajeú entre as ruas Dona Leopoldina e Rodrigues Júnior.

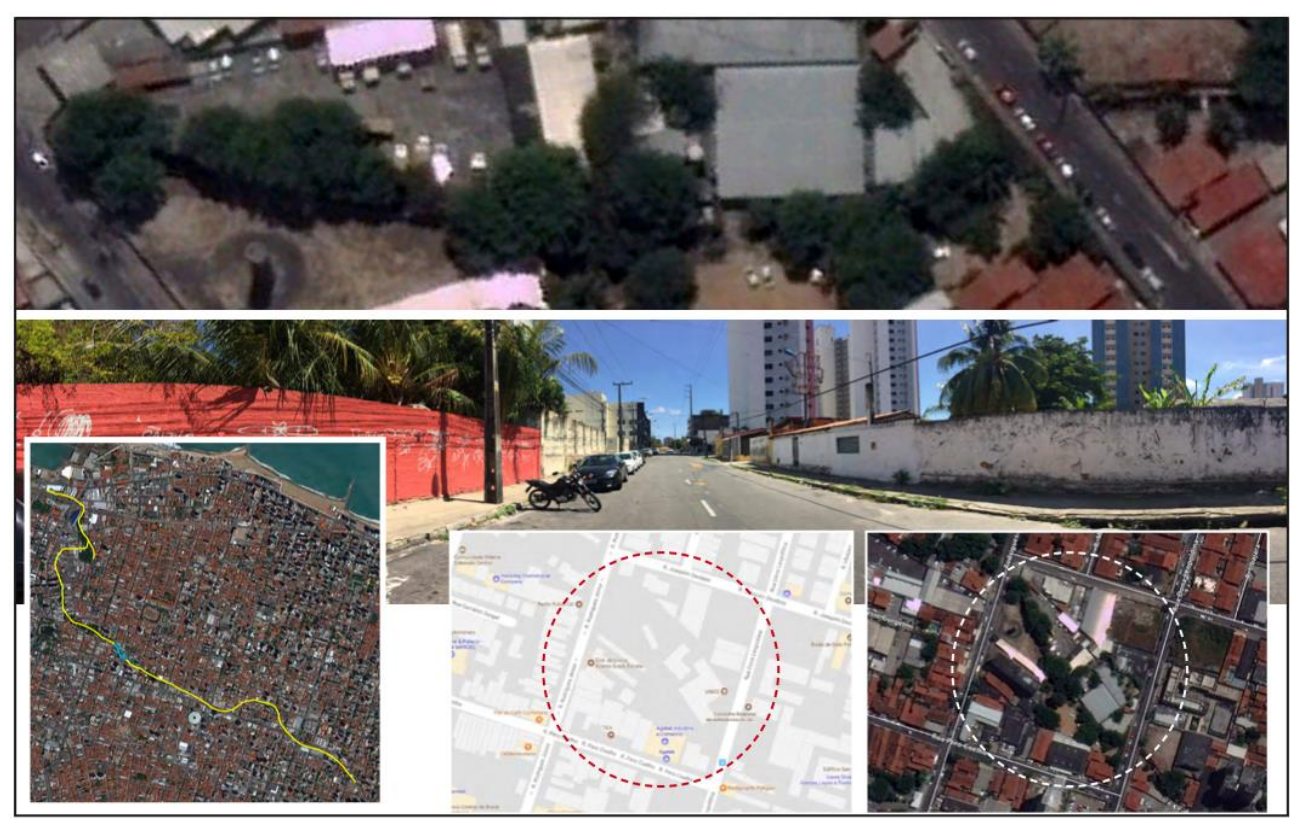

Fonte - Adaptado de Google Maps ${ }^{\circledR}$ (2017) e Google Earth Pro $^{\circledR}(30 / 09 / 2017)$. 
Figura 9 - Imagens de trecho exposto do curso do Riacho Pajeú em terreno localizado na rua Rodrigues Júnior.

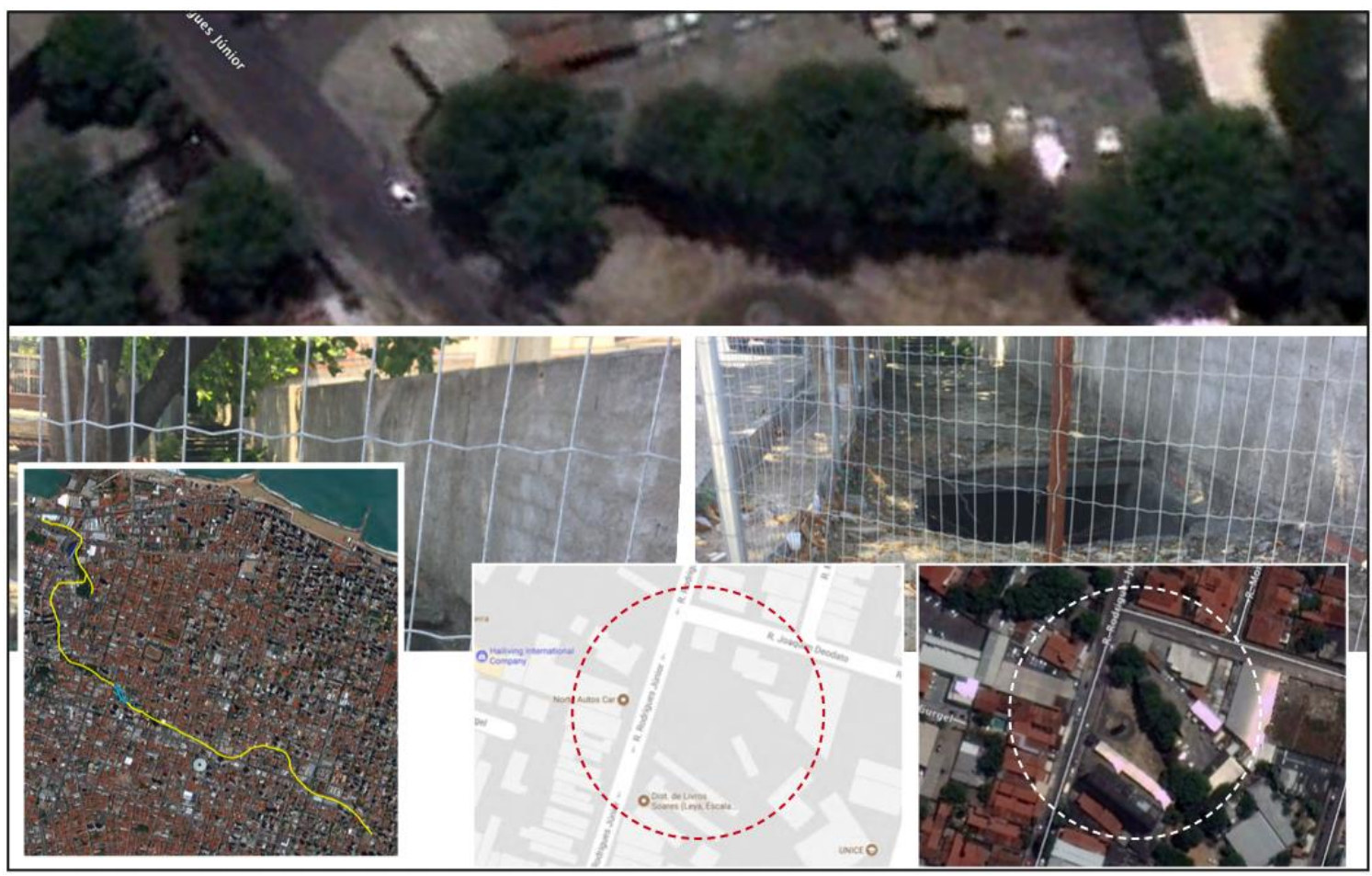

Fonte - Adaptado de Google Maps ${ }^{\circledR}$ (2017) e Google Earth $\operatorname{Pro}^{\circledR}(30 / 09 / 2017)$.

Figura 10 - Imagens de trecho da Rua Dom Manuel. À esquerda, residência particular apresentando a calha do riacho encoberta por concreto. À direita, o Parque Pajeú.

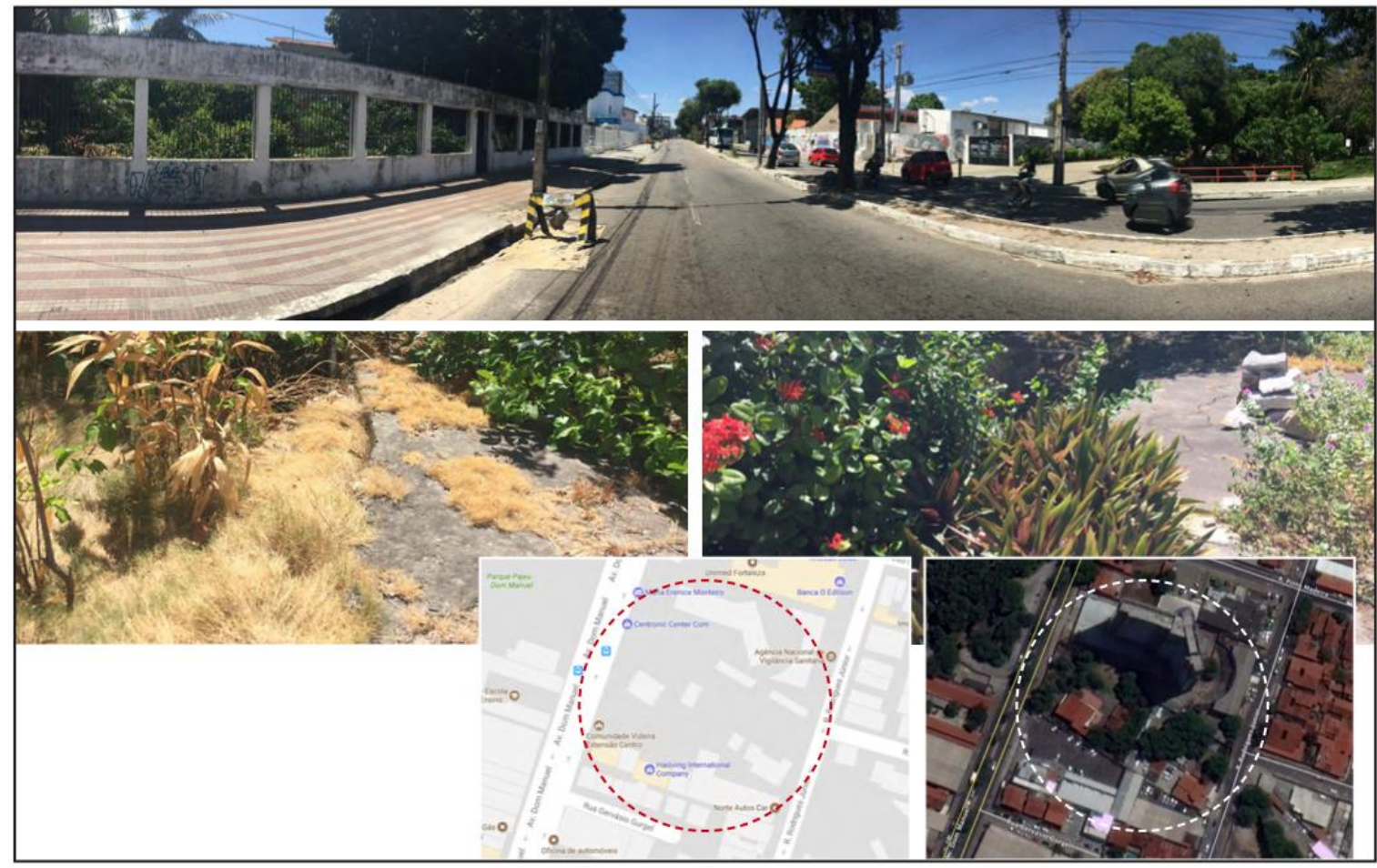

Fonte: Adaptado de Google Maps ${ }^{\circledR}$ (2017) e Google Earth Pro ${ }^{\circledR}(30 / 09 / 2017)$. 


\section{Quadrante D}

Nesse Quadrante (D), observa-se o último afloramento, no interior de uma propriedade particular (residencial), até perpassar sob a avenida Dom Manuel através de um canal e ressurgir já no primeiro segmento do Parque Pajeú, descrito anteriormente. O referido Parque (Figura 11) se constitui na maior extensão contínua do Riacho Pajeú a céu aberto em área pública.

Após atravessar todo o Parque Pajeú, o riacho adentra novo canal fechado, por sob a Rua Pinto Madeira, para ressurgir, do outro lado da rua, no interior do estacionamento, atravessando-o com leve curva através de um canal de rochas e terra com cerca de 3 metros, a céu aberto, assoreado por folhas e detritos, onde atravessa uma ponte de concreto e adentra um canal coberto que dá para o terreno adjacente.

Nesse próximo terreno (Figura 12), aflora novamente, nos fundos de um estabelecimento comercial, o Estacionamento Central Park, em canal com paredes de concreto, com cerca de 3 metros, também assoreado por folhas, detritos e vegetação arbustiva. Em seguida, adentra em novo canal encoberto, para ressurgir em canal exposto no terreno seguinte, também um estacionamento, já muito mais assoreado e recoberto por vegetação arbustiva e lixo, sendo praticamente impossível de se notar a presença de um curso d’água.

Novamente penetra em um canal encoberto e ressurge do outro lado do muro, nos fundos de mais um estacionamento, nas mesmas condições do afloramento anterior, assoreado por detritos e totalmente encoberto por vegetação. Uma última vez, nos fundos de mais um estacionamento, o riacho ressurge canalizado, já menos assoreado, onde já se pode visualizar o pequeno fluxo de água que corre entre detritos diversos, penetrando em novo canal encoberto pela Rua Pedro Borges.

Após atravessar a Rua Pedro Borges, ressurge, exposto de forma canalizada, nos fundos de um equipamento comercial (Edifício Portugal), em local com acesso exclusivo por autorização da Administração do edifício, mas visível a partir do piso térreo do mesmo. Nesse trecho o riacho também se apresenta parcialmente assoreado por detritos, folhas e vegetação arbustiva. Em seguida, por cerca de três quadras, corre totalmente encoberto por sob galpões e armazéns comerciais, herança de seu passado histórico de entreposto comercial nas proximidades da zona portuária de Fortaleza. Apesar do movimento intenso de trabalhadores e clientes percorrendo as estreitas ruas dessa intensa zona comercial, nenhum dos transeuntes, ao ser indagados informalmente, soube dizer algo sobre a existência de um riacho naquela porção do espaço, circulando próximos do Pajeú sem o perceberem.

Figura 11 - Imagens de trecho do Parque Pajeú, limítrofe à Avenida Dom Manuel.

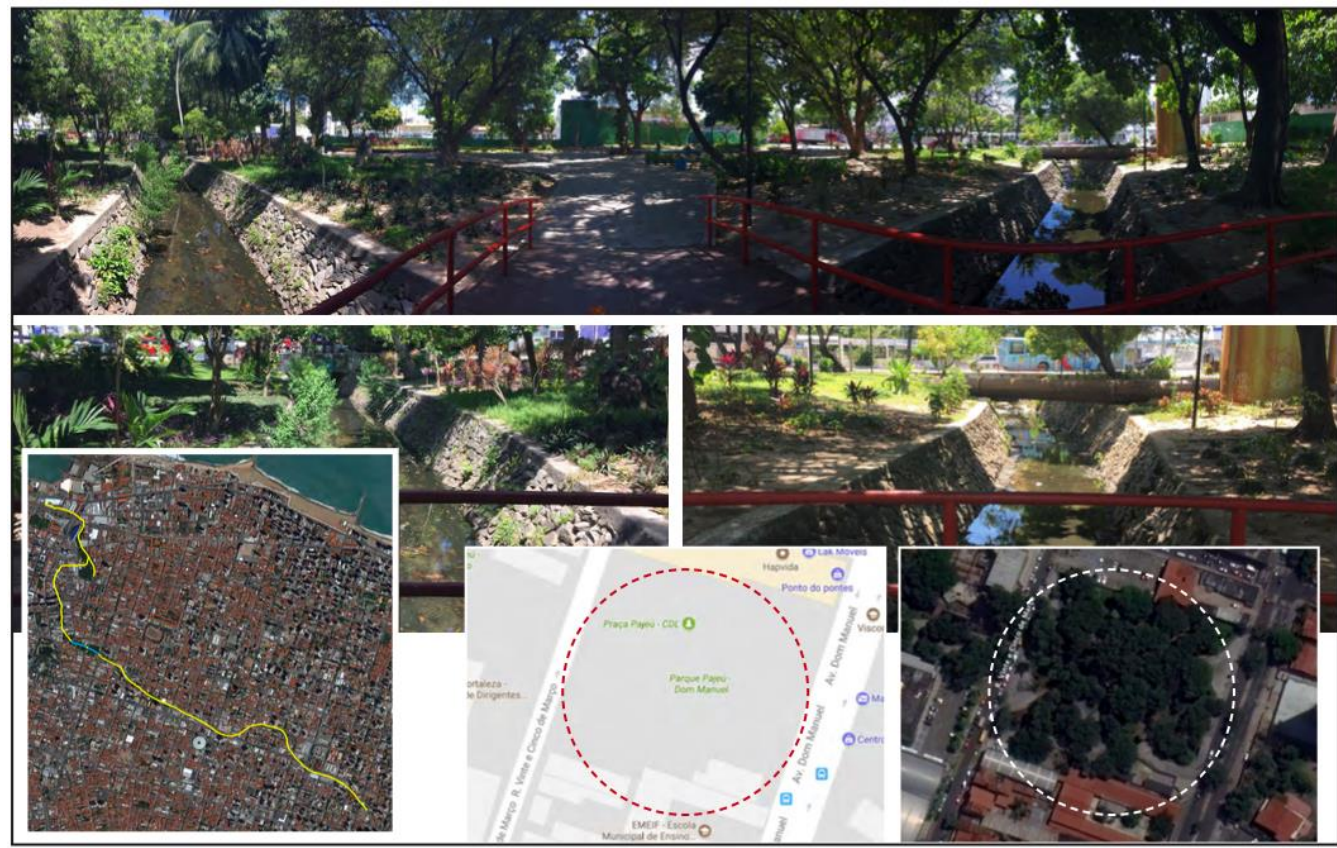

Fonte - Adaptado de Google Maps ${ }^{\circledR}$ (2017) e Google Earth Pro ${ }^{\circledR}(30 / 09 / 2017)$. 
Figura 12 - Imagens de trecho exposto do curso do Riacho Pajeú no interior do Estacionamento Central Park, na rua Sena Madureira.

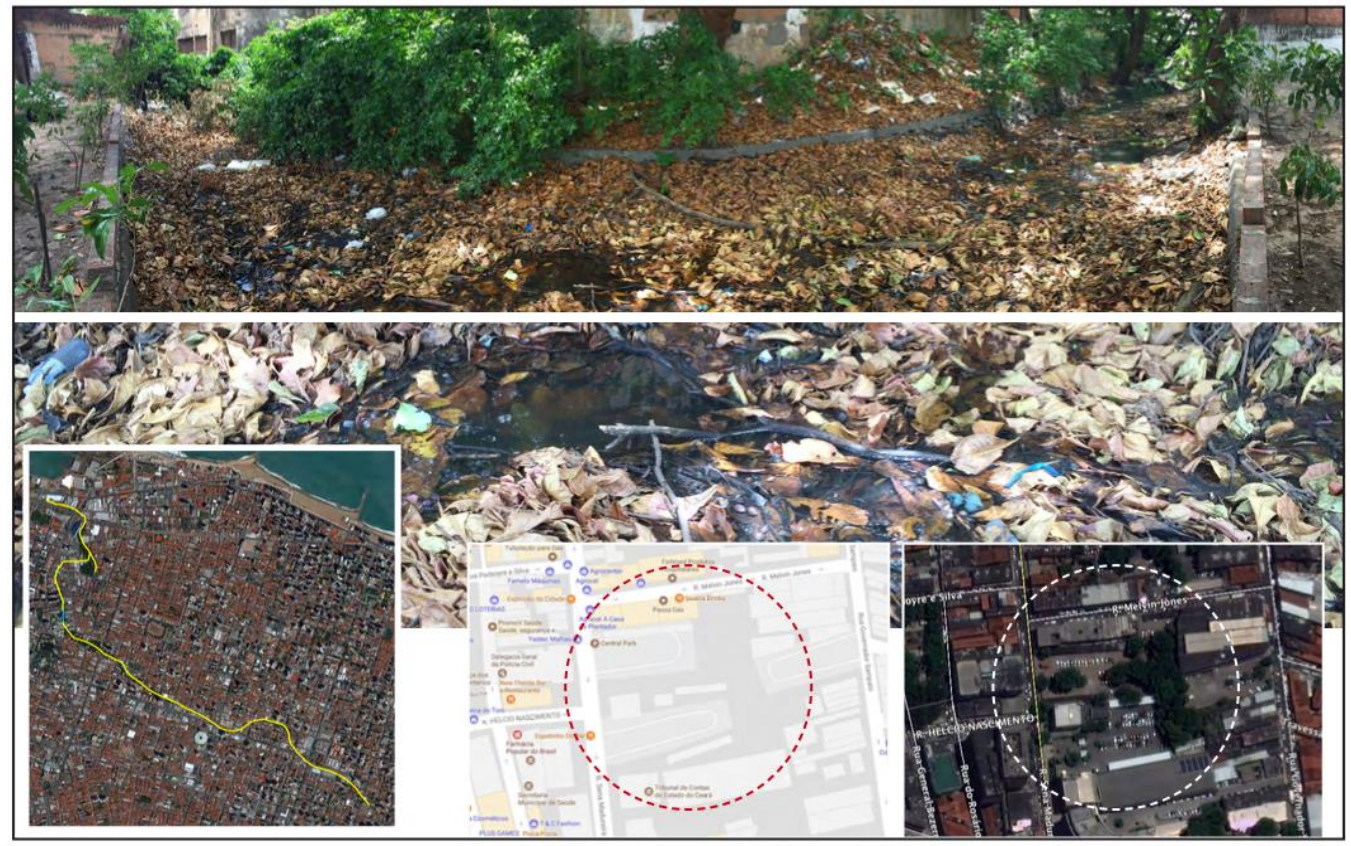

Fonte - Adaptado de Google Maps ${ }^{\circledR}$ (2017) e Google Earth Pro ${ }^{\circledR}(30 / 09 / 2017)$.

\section{Quadrante E}

Nesse Quadrante (E), observa-se os trechos do curso do Riacho Pajeú que afloram no interior do Paço Municipal e nos fundos do Mercado Central. No primeiro, encontra-se com suas margens urbanizadas e com tratamento paisagístico, mas, quando comparado à carta do Exército, observa-se uma alteração em seu curso original.

O acesso aos jardins do Paço Municipal, apesar de se tratar de um prédio público, se dá através de autorização do Departamento de Comunicação Social da Prefeitura, em dias e horários préagendados, então, de certo modo, continua indisponível para o acesso da maioria da população.

Após atravessar por canalização por sob a rua Rufino de Alencar, o Riacho Pajeú ressurge na área de estacionamento do Mercado Central de Fortaleza (Figura 13), em canal com cerca de 4 metros de largura e formado por muros de rocha, sem a presença de vegetação, mas, também, excessivamente assoreado por detritos. Trata-se do último trecho visível do curso do riacho passível de ser observado a céu aberto, antes de, novamente, perder-se em canais subterrâneos por sob a avenida Presidente Humberto de Alencar Castelo Branco (popularmente conhecida como avenida Leste-Oeste) e o complexo do estaleiro da Indústria Naval do Ceará S. A. (INACE), construído em 1969 sobre uma outrora Praia Formosa, próximo à Comunidade do Poço da Draga, e onde se localizaria a foz original do Riacho Pajeú. Cabe observar que não se obteve autorização da Direção da INACE visitar o estaleiro com o objetivo de documentar e registrar a atual foz do riacho.

Comparando-se a carta do Exército com as imagens de satélite obtidas através do aplicativo Google Earth Pro ${ }^{\circledR}$ em 30 de setembro de 2017, é possível afirmar que seu curso foi alterado em função das construções edificadas no local. Pelos dados oficiais constantes do Programa de Drenagem Urbana de Fortaleza (DRENURB), a foz do Riacho Pajeú, canalizada, se encontra ao final da avenida Alberto Nepomuceno, desaguando no Oceano Atlântico.

Assim, uma outrora praia, de acesso público, foi alienada pelo Capital em detrimento de seu uso comum, e a foz de um de seus mais importantes recursos hídricos, senão o mais importante em função de sua correlação histórica com os cidadãos fortalezenses foi, novamente, invisibilizada e suprimida da Paisagem, do Espaço e da memória de sua população. 
Figura 13 - Imagens de trecho exposto do curso do Riacho Pajeú por detrás do Mercado Central de Fortaleza, na avenida Alberto Nepomuceno.

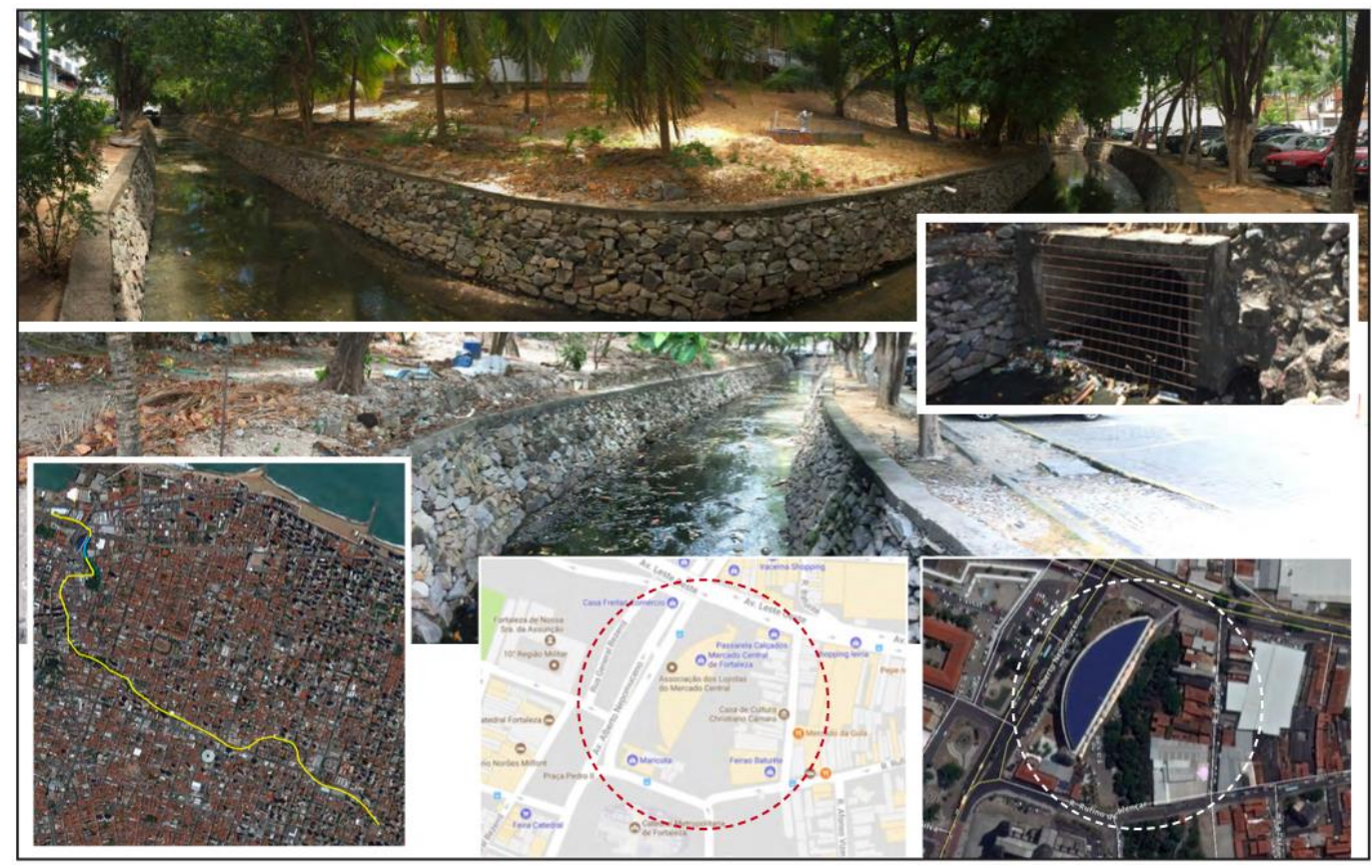

Fonte - Adaptado de Google Maps ${ }^{\circledR}$ (2017) e Google Earth Pro ${ }^{\circledR}(30 / 09 / 2017)$.

\section{ANÁLISE E TRATAMENTO DAS INFORMAÇÕES / DADOS OBTIDOS}

Conforme afirmado por Emlen (1974), a cidade pode ser observada como um ecossistema em desequilíbrio dinâmico frágil que, pela contínua e impactante ação humana, distancia-se do meio natural. Tal situação foi possível de ser observada a partir da análise das imagens de satélite e das incursões em campo, onde teve-se um melhor entendimento do processo de crescimento do Centro da cidade e o modo como se deu a invisibilização do Riacho Pajeú, apesar de sua importância para o processo de formação de Fortaleza e do seu histórico papel para a biodiversidade local.

Outrora um marco histórico de Fortaleza, o Pajeú foi excluído da paisagem urbana, tornando-se um desafio para as novas gerações construir um vínculo afetivo com o seu passado de relevante importância cênica, paisagística e ambiental. Nesse sentido, o Riacho Pajeú e a biodiversidade da paisagem às suas margens foram de tal forma suprimidos pelos fluxos promovidos pela metropolização extrema que se põe em xeque a complexidade em se recriar as condições ambientais e sociais que redefiniriam esse lugar. O espaço coletivo foi completamente apropriado pelo capital, e o espaço foi quase que totalmente alienado da população de seu entorno, distanciando-a do sentimento de pertencimento ao Riacho. Ocorre um processo de estranhamento entre a cidade e a região, alienando a própria espacialidade, uma vez que essa não mais serve às necessidades reais de seus habitantes (SANTOS, 2009).

Segundo Maria Cecília Barbieri Gorski (2010), as decisões equivocadas tomadas pelos gestores públicos, insustentáveis sob o ponto de vista urbanístico e ambiental, geram uma problemática que deveria levar em conta propostas de recuperação desses importantes corpos hídricos urbanos, o que, na prática, não acontece. Dadas as características dos principais agentes promotores do espaço urbano em Fortaleza (Estado, os proprietários fundiários e os promotores imobiliários), torna-se um desafio crer num redirecionamento das políticas citadinas com vistas ao resgate do Riacho Pajeú. Tal situação vem na contramão de iniciativas atuais de resgate e recuperação de rios urbanos que estão sendo colocadas em prática em diversas cidades do mundo.

Somente pequenos trechos do riacho ainda podem ser observados na paisagem urbana, principalmente na área compreendida pelo Parque Pajeú (entre a rua Pinto Madeira e a avenida Dom Manuel), nos jardins do Paço Municipal (a partir da rua São José) e por detrás do Mercado Central de Fortaleza. Nos dois primeiros o Pajeú sofreu algumas intervenções paisagísticas, mas, no último, 
caracteriza-se por um pequeno fluxo de água canalizado entre paredes rochosas. Outros afloramentos ocorrem, porém localizados em espaços privados de difícil acesso.

Esse processo de canalização e cobertura de grande parte do curso do Riacho Pajeú contribui para a ocorrência de problemas socioambientais em seu entorno, indo desde a perda do sentimento de pertencimento associado à invisibilização do Riacho até a perda de áreas verdes que contribuiriam para uma equilíbrio ambiental, resultando em prejuízos à biodiversidade, microclima e crescimento de áreas de inundações crônicas.

Levando em conta o papel de importância da conservação dos recursos hídricos, torna-se essencial que as políticas voltadas a sua gestão evoluam constantemente. Nesse contexto, pela legislação vigente, as Áreas de Preservação Permanente (APP's) surgem enquanto espaços territoriais especialmente protegidos de acordo com o disposto no inciso III, $\S 1^{\circ}$, do art. 225 da Constituição Federal (BRASIL, 1988). Também o Código Florestal Brasileiro detalha precisamente as Áreas de Preservação Permanente. As APP's são aquelas áreas protegidas nos termos dos arts. $2^{\circ}$ e $3^{\circ}$ do Código Florestal (BRASIL, 2012). O conceito legal de APP relaciona estas áreas com a "função ambiental de preservar os recursos hídricos, a paisagem, a estabilidade geológica, a biodiversidade, o fluxo gênico de fauna e flora, proteger o solo e assegurar o bem-estar das populações humanas". Assim, as APP's possuem uma função de proteção de espaços de relevante importância para a qualidade ambiental visando assegurar o bem-estar das populações humanas, e não somente preservar a vegetação ou a biodiversidade.

O Código Florestal prevê faixas e parâmetros para as distintas tipologias de APP's, de acordo com a característica de cada área. No caso das margens dos cursos d'água (rio, nascente, vereda, lago ou lagoa), a norma considera o estado de conservação da vegetação, a largura e as características do curso d'água a ser protegido. Para as nascentes (perenes ou intermitentes) a lei estabelece um raio mínimo de 50 metros no seu entorno independentemente da localização, em área rural ou urbana. Em seu Art. $2^{\circ}$, consideram-se de preservação permanente as florestas e demais formas de vegetação natural situadas ao longo dos rios ou de qualquer curso d'água desde o seu nível mais alto em faixa marginal cuja largura mínima será de 30 (trinta) metros para os cursos d'água de menos de 10 (dez) metros de largura.

Não é o que se nota no caso do Riacho Pajeú, cujas margens estão densamente povoadas, apesar de figurar nos projetos públicos como inserido em área de proteção ambiental. A invisibilização do Riacho Pajeú não se dá apenas nos trechos em que se encontra encoberto. Também nas poucas áreas de curso exposto, em geral no interior de propriedades privadas, tal característica persiste.

Na Figura 14 observa-se o curso original do Riacho Pajeú determinado pelo Serviço Geográfico do Exército em 1945, em seus segmentos expostos (modificados ou subterrâneos), denotando sua "invisibilidade" na paisagem fortalezense na maior parte do mesmo, sobretudo nas áreas mais valorizadas e de maior concentração econômica. Sua nascente e a maior parte do curso inicial encontra-se no bairro da Aldeota, correndo sob o subsolo por baixo de complexos de apartamentos, concessionárias de automóveis, restaurantes, clínicas e outros estabelecimentos comerciais. Observa-se, também, alterações em seu curso original em virtude da construção de grandes empreendimentos comerciais e residenciais, tais como universidade e conjuntos residenciais.

Fortaleza avançou ao longo de sua história em direção ao Riacho Pajeú, o qual sofreu degradação e passou a ser ocultado sob vias e limitado por taludes de concreto. Tal relação não é percebida apenas naquele rio, mas configura-se enquanto uma constante na relação da gestão da cidade com seus recursos hídricos, com notoriedade para os rios Ceará (à oeste) e Cocó (à sudeste), importantes bacias que sofrem na atualidade com o lançamento de efluentes e desmatamento de suas vegetações ripárias. Assim, diante da ausência de uma gestão dos recursos hídricos, os mesmos deixam de consistir em uma referência paisagística para a cidade e passam a adquirir uma conotação negativa (ALVE, 2006), sendo lócus de vulnerabilidade socioambiental. 
Figura 14 - Imagem ilustrativa do curso do Riacho Pajeú, desde sua nascente até próximo a sua foz, indicando seus trechos originais expostos, modificados e subterrâneos.

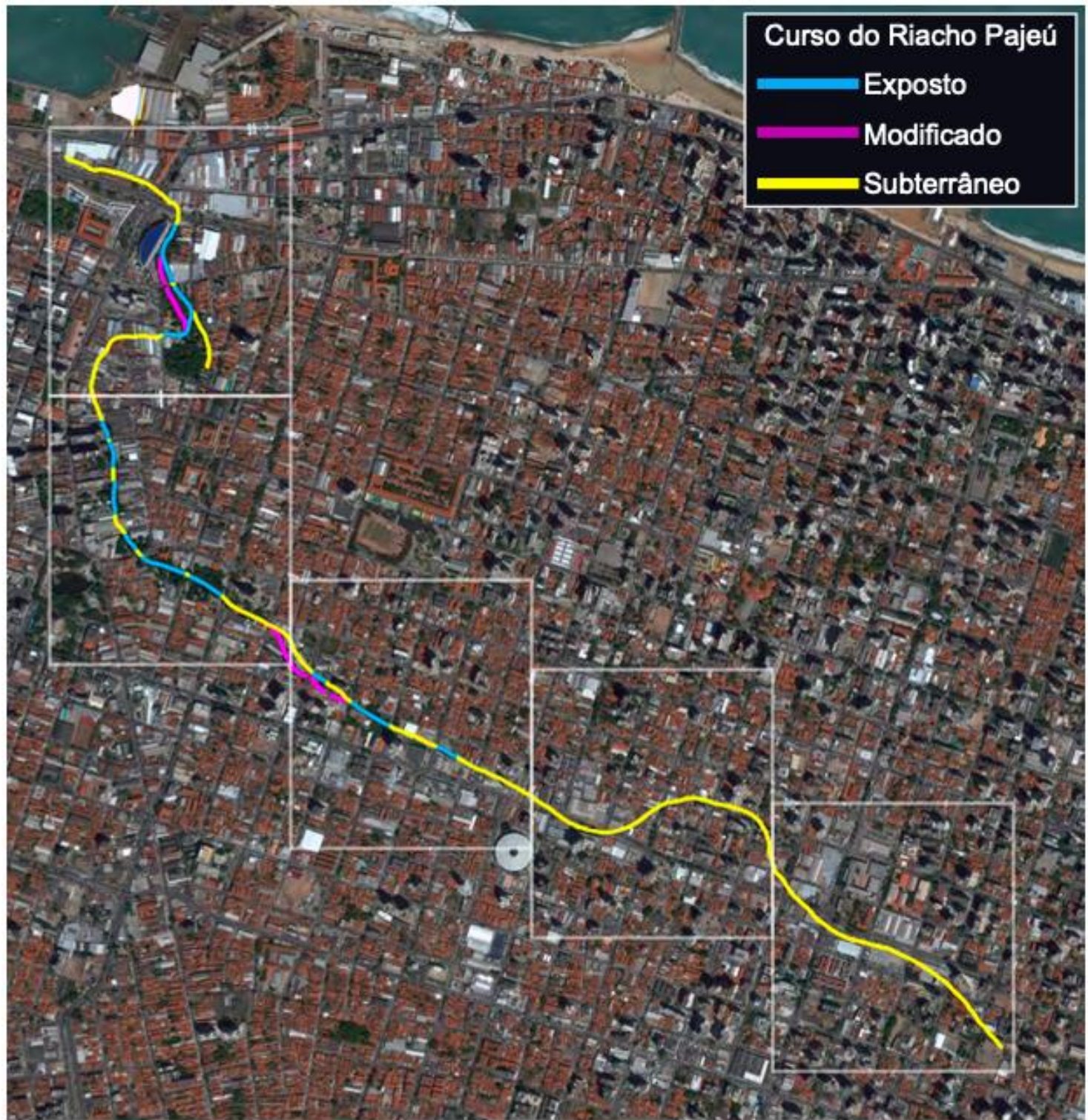

Fonte - Adaptado do Google Earth Pro® (30/09/2017). Escala 1:10.000.

\section{CONSIDERAÇÕES FINAIS}

A paisagem da cidade de Fortaleza, como ocorre com praticamente todas as cidades ao longo do tempo, sofreu significativa alteração em virtude de seu processo de expansão e urbanização. Nesse contexto, marcos históricos e geográficos como o Riacho Pajeú, presente no imaginário fortalezense desde a fundação da cidade foram sendo depreciados e gradativamente relegados pela urbanização desordenada e especulação imobiliária.

Atualmente, apenas uma pequena parte do curso original desse riacho pode ser observado a céu aberto. Sua maior parte foi encoberta, canalizada ou mesmo sofreu alteração em virtude de interesses particulares e, até mesmo, públicos. Tal situação levanta a questão: afinal, como preservar a memória daquilo que não se pode ver ou sentir? A memória afetiva e o sentimento de pertencimento precisam de estímulos, inclusive visuais, para desencadear toda espécie de sensações de empatia com o referido espaço.

O ser humano, em sua busca desenfreada pelo "bem-estar" da vida cotidiana, há muito vem se desconectando de suas raízes e de sua herança cultural, criando novos ícones e recriando uma

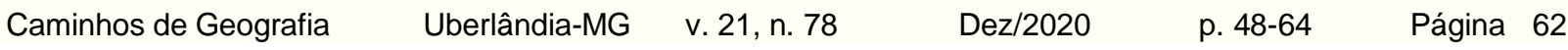


"natureza" artificial que melhor se adeque às suas necessidades e anseios contemporâneos. Os elementos naturais originais passaram de objetos de referência para obstáculos a serem transpostos, contornados ou "requalificados", termo técnico recorrentemente utilizado pelo poder público para alterar as características originais de determinada região para atender ao "interesse social", como se a qualidade ambiental não fosse um atributo que atendesse a esse interesse.

Mesmo os poucos trechos do curso do Riacho Pajeú que podem ser percebidos na paisagem perderam sua identidade natural, transformando-se em meros canais por meio dos quais todo tipo de efluentes são descartados, contribuindo para a aceleração do processo de degradação ambiental do mesmo. Serpenteia por entre prédios, casas e quintais, subvalorizado e destituído de seu valor referente aos serviços ambientais que presta à população e ao meio urbano.

Muitas das mazelas da cidade no entorno de seu curso poderiam ser explicadas caso se conhecesse e procurasse entender melhor a dinâmica desse riacho. Episódios cíclicos de inundações em épocas de quadras chuvosas poderiam ser compreendidos se resgatássemos sua importância para a paisagem fortalezense, uma vez que o atual leito do Pajeú, reduzido artificialmente, não é capaz de suportar a carga hídrica excedente.

Rios são corpos vivos, dinâmicos, que reagem ao e/ou com o ambiente, necessitando de espaço para expandir seus fluxos quando há um aporte maior de água em seus leitos e, esses, estando canalizados, pressionados e assoreados, se comportam de maneira caótica na busca por um novo equilíbrio, aprisionados em paredes e dutos, fluindo sempre para áreas de escape traduzidas em ruas, avenidas, etc. Pode-se observar, também, mudanças de seus cursos originais para beneficiar empreendimentos imobiliários ou mesmo instalações públicas, como ocorreu com a foz do Riacho Pajeú, quando da construção da Avenida Leste-Oeste e a urbanização e tratamento paisagístico do Paço Municipal. Conclui-se, portanto, que deveria ser empreendido um esforço para recuperar os trechos de seu leito ainda presentes na paisagem da cidade, desobstruindo-se e ampliando sua calha de inundação, bem como, sempre que possível, reabrir trechos hoje encobertos, reflorestando suas margens e devolvendo à paisagem sua função ambiental e afetiva.

\section{AGRADECIMENTOS}

Agradecemos à Prefeitura de Fortaleza, pela autorização para a visita às dependências dos Jardins do Paço Municipal.

\section{REFERÊNCIAS}

ALMEIDA, Lutiane Queiroz de. Vulnerabilidades Socioambientais de Rios Urbanos: bacia hidrográfica do rio Maranguapinho, região metropolitana de Fortaleza, Ceará. Tese (Doutorado em Geografia) - Rio Claro: Instituto de Geociências e Ciências Exatas/Universidade Estadual Paulista. 2010. 278p.

ALVE, Maristela Pimentel. Rios urbanos e paisagem regional: o caso da bacia do Rio Emscher/Alemanha. Paisagens em debate, n. 4, dez. 2006. Disponível em: $<$ http://www.fau.usp.br/depprojeto/gdpa/paisagens/artigos/2006Maristela-Emscher.pdf>. Acesso em 10 ago. 2020.

ANDRADE, João Angelo Peixoto de; MATOS, Fábio de Oliveira. Nas trilhas da educação ambiental: por uma relação renovada com ecossistemas manguezal. Geosaberes, Fortaleza, v. 7, n. 12, p. 91 - 103, maio 2016. ISSN 2178-0463. Disponível em: <http://www.geosaberes.ufc.br/geosaberes/article/view/525>. Acesso em: 01 de mar. de 2020. https://doi.org/10.26895/geosaberes.v7i12.525

BIBLIOTECA NACIONAL. Acervo Digital. Disponível em: < http://objdigital.bn.br/acervo_digital> Acesso em: 10 fev. 2020.

BOBADILHO, Rosani Sola. A Problemática dos Rios Urbanos Costeiros: entraves e possibilidades para a qualidade ambiental e social. Dissertação (Mestrado em Gerenciamento Costeiro) - Rio Grande: Universidade Federal do Rio Grande. 2014. 210 p.

BRASIL. Lei № 12.651, de 25 de Maio de 2012. Código Florestal Brasileiro. 2012. Disponível em: http://www.planalto.gov.br/ccivil_03/_ato2011-2014/2012/lei//12651.htm. Acesso em: 10 de fevereiro de 2020. 
BRASIL. Constituição da República Federativa do Brasil de 1988. 1988. Disponível em: http://www.planalto.gov.br/ccivil_03/constituicao/constituicao.htm Acesso em: 10 de fevereiro de 2020.

COSGROVE, Denis. A Geografia Está em Toda Parte: Cultura e simbolismo nas paisagens humanas. In: CORRÊA, Roberto Lobato; ROZENDAHL, Zeny (org.). Paisagem, Tempo e Cultura. Rio de Janeiro: Eduerj, 1998. p. 92-123.

EMLEN, John. An Urban Bird Community in Tucson, Arizona: Derivation, Structure, Regulation. The Condor, Colorado, n. 76, p. 184-197, 1974. https://doi.org/10.2307/1366729

GORSKI, Maria Cecília Barbieri. Rios e Cidades: ruptura e reconciliação. São.Paulo: Ed. SENAC, 2010.

KAHTOUNI, Saide. Cidade das Águas. Ed. Rima. São Paulo, 2004. 159 p.

PREFEITURA MUNICIPAL DE FORTALEZA. Projeto Fortaleza Cidade Sustentável: marco de gestão socioambiental. Fortaleza: Secretaria Municipal de Urbanismo e Meio Ambiente (SEUMA), 2016. 168 p.

PREFEITURA MUNICIPAL DE FORTALEZA. Lei Complementar № 062. Plano Diretor Participativo do Município de Fortaleza (PDPFOR). Fortaleza: Câmara Municipal, 2009.

PREFEITURA MUNICIPAL DE FORTALEZA. Inventário ambiental de Fortaleza. Fortaleza: Secretaria Municipal do Meio Ambiente (SEMAN), 2003. 410 p.

PREFEITURA MUNICIPAL DE FORTALEZA. Parque Pajeú. Fortaleza: Superintendência de Planejamento do Município, 1981. 22 p.

SANTOS, Milton. Pensando o Espaço do Homem. $5^{a}$ Ed. São Paulo: Edusp Editora da Universidade de São Paulo, 2009. 90p.

SERPA, Angelo. Milton Santos e a Paisagem: Parâmetros para a Construção de uma Crítica da Paisagem Contemporânea. Paisagem e Ambiente, (27), p. 131-138, 2010. https://doi.org/10.11606/issn.23595361.v0i27p131-138

TUNDISI, José Galizia; TUNDISI, Takako Matsumura. Limnologia. São Paulo: Oficina de Textos, 2008. $632 \mathrm{p}$.

Recebido em: 01/03/2020

Aceito para publicação em: 06/08/2020 